\title{
Recommendations for the management of acute lower respiratory tract infections in children under 2 years of age, 2021. Considerations for strengthening the first level of care
}

Acute lower respiratory tract infections (ALRTIs) continue to be an important cause of morbidity and mortality in infants in Argentina and the world. ${ }^{1}$ In this age group, most cases of ALRTIs (bronchiolitis or pneumonia) are caused by respiratory viruses, with seasonal distribution during the cold months of the year in regions with a temperate climate. ${ }^{2}$ Their diagnosis is largely clinical, and most of these conditions are selflimited and without complications; treatment is based on supportive measures at home. A small group of patients may require hospitalization in general wards and, of these, approximately $2 \%$ in intensive care units. ${ }^{3}$

Evidence shows that the presence of biological factors (age under 3 months old, prematurity / low birth weight, comorbidities, etc.) and socioenvironmental risk factors are associated with a higher rate of complications, hospitalization, and death (many of them at home). ${ }^{4,5}$

Given the high prevalence of ALRTIs, standardized case management is a valuable tool for dealing with them. This standardized approach, based on the best available evidence, proposes safe care practices with a rational use of resources. This initiative takes into account risk factors and social determinants, thereby enabling the optimization of decisions as of the first level of care.

The Sociedad Argentina de Pediatría was a pioneer in the standardization of ALRTI management. In 1996, it took up the challenge of developing a guideline for the comprehensive management of patients with these conditions. ${ }^{6}$ In its first version, the document not only included the most important guidelines for the treatment of ALRTIs, but also underscored those measures to be avoided. The main emphasis was on promoting the rational use of antibiotics, endorsing their use only when necessary. Different widespread practices, deeply rooted among health care providers, were also described. These approaches lack a sound scientific evidence-base and therefore should be avoided in the routine management of these patients (i.e., the use of systemic and/or inhaled corticosteroids, nebulizations, decongestants, chest physiotherapy, mucolytic agents, ancillary tests such as chest X-rays, etc.). Another characteristic of the document was that it was structured keeping in mind all levels of complexity, but empowering the primary health care team as the key player in the comprehensive management of these children, including outpatient follow-up, appropriate treatment and, occasionally, timely referral.

Over time, this measure proved effective in managing most of the cases at this first level of care, thereby freeing up a significant number of resources for severely ill patients. In addition, ALRTI programs have favored the reinforcement of prevention measures and the promotion of outpatient follow-up practices using low complexity technology, close to home and in a family-friendly setting. ${ }^{7,8}$

This recommendation has been updated by the Sociedad Argetnina de pediatría three times: in $2005,{ }^{9}$ in $2015,{ }^{10}$ and the latest one, in 2021. ${ }^{11}$ In each new version, a number of amendments were made in the light of new evidence, always adjusted to our local reality. This task was coordinated by the National Committee of Pediatric Pulmonology, with contributions from the Committees of Infectious Diseases, Internal Medicine, and Outpatient Pediatrics. Besides, as usual, the steering role of national health authorities was strengthened to ensure the effective implementation of the recommendations in all jurisdictions. ${ }^{12}$

This latest version (2021) underscores the importance of biological and socio-environmental risk factors both in the first visit as well as in the follow-up of infants with ALRTIs. It also reinforces the concept that bronchodilators should only be used in the context of an empirical therapy trial. Likewise, the need to improve the early detection and diagnosis of hypoxemia in the initial assessment, as well as in situations of increased risk of complications or death is emphasized in order to act accordingly.

After 25 years, we reassert the key aspects of the recommendation still in force in 2021:

- Admission of the patient to the health system with primary care as the first point of contact (in coordination with the referral network).

- Comprehensive assessment of the patient and their setting, including the patient's severity and risk factors. 
- Routine clinical observation of the infant for a brief and limited period of time, but long enough to adequately assess the infant's clinical status and the response to measures adopted.

- Decision on the patient's fate based on the severity, progress made during the period of observation and existing risk factors, including the options of outpatient management or referral to a health center of higher complexity, as appropriate.

- Community dissemination of prevention measures, awareness of warning signs, the need for early consultation, and compliance with follow-up visits until definitive discharge. In the context of the SARS-CoV-2 pandemic, or other specific epidemiological situations, recommendations should be adjusted in a timely manner based on the provisions issued by health authorities.

For more detailed information on the recommendations, we suggest reading the document "Recommendations for the management of acute lower respiratory tract infections in children under 2 years of age. Update 2021". ${ }^{11}$

We believe that this material will be most helpful to those carrying out the most important part of the job: accompanying children and their families in a time when they need this the most.

\section{Laura Moreno $0^{a, b}$ Sandra Barría $a^{a, c}$}

Fernando Ferrero ${ }^{a, d}$

a. National Committee of Pediatric Pulmonology, Sociedad Argentina de Pediatría.

b. Chair of Clinical Pediatrics. Universidad Nacional de Córdoba.

c. Hospital Regional Víctor Manuel Sanguinetti. Comodoro Rivadavia. Chubut.

d. Hospital General de Niños "Pedro de Elizalde," Autonomous City of Buenos Aires, Argentina.

http: / / dx.doi.org/10.5546/ aap.2021.eng.292
To cite: Moreno L, Barría S, Ferrero F. Recommendations for the management of acute lower respiratory tract infections in children under 2 years of age, 2021. Considerations for strengthening the first level of care. Arch Argent Pediatr 2021;119(5):292-293.

\section{REFERENCES}

1. Shi T, McAllister DA, O'Brien KL, Simoes EA, et al. Global, regional, and national disease burden estimates of acute lower respiratory infections due to respiratory syncytial virus in young children in 2015: a systematic review and modelling study. Lancet. 2017; 390(10098):946-58.

2. Moriyama M, Hugentobler WJ, Iwasaki A. Seasonality of Respiratory Viral Infections. Annu Rev Virol. 2020; 7(1):83101.

3. Nair H, Simoes EA, Rudan I, Gessner BD, et al. Global and regional burden of hospital admissions for severe acute lower respiratory infections in young children in 2010: a systematic analysis. Lancet. 2013; 381(9875):1380-90.

4. Argentina. Ministerio de Salud y Desarrollo Social. Indicadores básicos Argentina 2019. [Accessed on: April $\left.15^{\text {th }}, 2021\right]$. Available at: http://www.deis.msal.gov.ar/ wp-content/uploads/2019/12/Indicadores-Basicos-2019. pdf

5. Argentina. Ministerio de Salud. Natalidad y mortalidad infantil 2019. Boletín N¹63. Buenos Aires, January 2021. [Accessed on: April 15 ${ }^{\text {th }}$, 2021]. Available at: http:/ / www. deis.msal.gov.ar / files / DEIS_\%20Natalidad\%20y\%20 Mortalidad \%20Infantil\%202019_163\%20B.pdf

6. Ferrero F, González Pena H, Ossorio MF, Grenoville M. Consenso sobre infecciones respiratorias agudas bajas en menores de 2 años. Recomendaciones para su manejo. Arch Argent Pediatr. 1996; 94(4):274-88.

7. Speranza AM, Orazi V, Manfredi L, de Sarasqueta P. Programa Nacional de Infecciones Respiratorias Agudas Bajas. Hospitalización abreviada: Un modelo de atención basado en evidencias altamente efectivo para descender la mortalidad infantil. Arch Argent Pediatr. 2005; 103(3):282-7.

8. Grad E, Basso V, Jaquenod M. Programa de infecciones respiratorias agudas en la Provincia de Buenos Aires: resultados en 2019. Rev Argent Salud Pública. 2020; 12:e6.

9. Comité Nacional de Neumonología, Subcomisión de Epidemiología, Comité Nacional de Infectología, Comité Nacional de Medicina Interna. Recomendaciones para el diagnóstico y tratamiento de las infecciones respiratorias agudas bajas en menores de 2 años. Arch Argent Pediatr. 2006; 104(2):159-76.

10. Comité Nacional de Neumonología; Comité Nacional de Infectología; Comité Nacional de Medicina Interna. Recomendaciones para el manejo de las infecciones respiratorias agudas bajas en menores de 2 años. Resumen ejecutivo. Arch Argent Pediatr. 2015; 113(4):373-4.

11. Comité Nacional de Neumonología; Comité Nacional de Infectología; Comité Nacional de Medicina Interna. Recomendaciones para el manejo de las infecciones respiratorias agudas bajas en menores de 2 años. Actualización 2021. Arch Argent Pediatr. 2021; (accepted for publication). 